\title{
Seria Nietzsche um heideggeriano? Uma resposta a Vinicius Figueiredo*
}

\author{
Should Nietzsche be considered a Heideggerian thinker? An answer \\ to Vinicius Figueiredo
}

\author{
Fernando Costa Mattos \\ fcmattos1974@gmail.com \\ (Universidade Federal do ABC, São Paulo, Brasil)
}

\begin{abstract}
Resumo: 0 texto se constitui como uma resposta ao artigo de Vinicius Figueiredo "Seria Nietzsche um kantiano?", publicado nestes mesmos Cadernos de Filosofia Alemã (v.20, n.1), o qual, por seu turno, resenha criticamente o meu livro Nietzsche, perspectivismo e democracia: um espírito livre em guerra contra o dogmatismo (Saraiva, 2013). Em linhas gerais, procuro mostrar que, se Nietzsche não for interpretado como um continuador do projeto crítico kantiano, de matriz iluminista, ele acaba por aproximar-se, também no que diz respeito à compreensão da verdade, daquelas filosofias que, por oposição à epistemologia predominante no Ocidente, buscam um acesso direto ao ser caso da filosofia heideggeriana, que poderia ser vista como o ponto culminante de uma tradição que começa com os românticos.
\end{abstract}

Palavras-chave: Nietzsche; Kant; Heidegger; verdade; ser.

\begin{abstract}
The text is a response to Vinicius Figueiredo's article "Seria Nietzsche a Kantiano?" ("Should Nietzsche be considered a kantian thinker?"), published in these Cadernos de Filosofia Alemã (v.20, n.1), which, in turn, critically reviews my book Nietzsche, perspectivismo e democracia: um espírito livre em guerra contra o dogmatismo (Nietzsche, Perspectivism and democracy: a free spirit at war against dogmatism) (Saraiva, 2013). In general terms, I try to show that, if Nietzsche is not interpreted as a continuer of the Kantian critical project (rooted in the German Aufklärung), he ends up getting closer, also with respect to the understanding of truth, to those philosophies that, as opposed to the epistemology that prevails in the West, seek a direct access to being - which is the case of Heidegger's philosophy, which could be seen as the culmination of a tradition that begins with the Romantics.
\end{abstract}

Keywords: Nietzsche; Kant; Heidegger; truth; being.

DOI: http://dx.doi.org/10.11606/issn.2318-9800.v22i1p99-113

Em artigo intitulado "Seria Nietzsche um kantiano?", publicado no volume 20, número 1, destes mesmos Cadernos de Filosofia Alemã: Crítica e Modernidade, ${ }^{1}$ Vinicius Figueiredo estabelece um diálogo com meu livro Nietzsche, perspectivismo e democracia: um espírito livre em guerra contra o dogmatismo, ${ }^{2}$ tecendo algumas

* O presente texto é uma versão modificada do que apresentei no XIX Encontro de Pesquisa na Graduação em Filosofia da USP, em 14/04/2016.

1.Figueiredo, V. (2015). Seria Nietzsche um kantiano? Cadernos de Filosofia Alemã: Crítica e Modernidade, 20(1), pp.51-72.

2. Mattos, F. C. (2013). Nietzsche, perspectivismo e democracia: um espírito livre em guerra contra o dogmatismo. São Paulo: Saraiva 
críticas a ele. Meu objetivo, aqui, é reagir a essas críticas e, assim, dar continuidade a esse diálogo, pelo qual sou grato a Figueiredo. Começarei por um breve resumo de meu livro (versão ligeiramente modificada de minha tese de doutorado, defendida no Departamento de Filosofia da USP em 2007) e, em seguida, passarei ao texto de Figueiredo, do qual destacarei algumas críticas e sugestões para poder responder a elas, tendo em vista o modo como interpreto atualmente a filosofia de Nietzsche ou, sobretudo, a sua posição na filosofia contemporânea.

Antes de tudo, cabe salientar, como faz Figueiredo em seu artigo, e eu mesmo na Introdução ao livro, que ele não é um livro sobre Nietzsche, mas uma reflexão a partir de sua filosofia. Logo, ainda que Nietzsche seja a base teórica da tese, ele não constitui a fonte de verdade, por assim dizer, que pudesse funcionar como critério último para decidir acerca da validade das posições adotadas frente a ele. Isso levanta de saída uma questão metodológica que diz respeito à nossa atividade como pesquisadores em Filosofia: se devemos ser historiadores da Filosofia, à maneira estruturalista, ou se podemos ousar para além desses cânones; quais os limites entre uma coisa e outra; e assim por diante. Não pretendo entrar diretamente nesse assunto, mas é importante que ele fique desde logo sublinhado e, como está relacionado a uma das críticas feitas por Figueiredo, se mantenha como uma espécie de pano de fundo para esta discussão.

Feita essa ressalva preliminar, e procurando repensar hoje - mais de dez anos depois - o movimento que desenvolvi ao longo de minha pesquisa de doutorado, eu diria que meu objetivo principal era chegar com Nietzsche a uma posição de defesa da liberdade individual como instância de criação perspectivística e, assim, de realização autêntica das mais próprias e singulares possibilidades. Com relação a isso, porém, logo surgiram algumas dificuldades, a começar pela noção de indivíduo: para muitos intérpretes, como é sabido, a noção de vontade de poder conduziria Nietzsche a dissolver o indivíduo, inviabilizando a própria ideia de liberdade individual (donde sua crítica ao conceito liberal de liberdade). ${ }^{3}$ Se eu aceitasse essa interpretação, Nietzsche deixaria de ser uma boa base teórica para realizar a referida defesa: ou bem eu teria de mudar o meu autor, ou bem eu teria de encontrar no próprio Nietzsche um modo de conciliar a sua filosofia - notadamente a sua face propositiva (onde se destacam noções como "espírito livre", "além-do-homem", "autossuperação", "como tornar-se o que se é", etc.) - com algum conceito minimamente positivo de "indivíduo" (ainda que entre aspas).

De certo modo, foi esse o propósito que animou o movimento de meu primeiro capítulo, intitulado "Do universal ao singular: o conhecimento na perspectiva do indivíduo": tratava-se de mostrar que o projeto filosófico nietzschiano tem por base o perspectivismo, entendido este como uma espécie de pressuposto epistemológico,

3 Para uma boa e atualizada discussão sobre este assunto, cf. Gori, P. e Stellino, 2014. 
e que o perspectivismo supõe a instauração de perspectivas a partir de "focos perspectivadores" singulares (ou vontades de poder no plural, conforme a conhecida tese de Müller-Lauter (2009)). Estes não coincidem necessariamente com os indivíduos humanos (longe disso, aliás), mas podem assumir também essa configuração, e é ela que nós - cada um de nós, indivíduos humanos de carne e osso, não excluído o Sr. Nietzsche - efetivamente vivenciamos enquanto "focos perspectivadores". Daí Nietzsche definir o indivíduo como uma "ficção necessária à vida", e falar sempre nas suas verdades (com grifo no pronome pessoal), nas suas hipóteses e assim por diante.

Note-se que não estou aí atribuindo qualquer substancialidade à noção de indivíduo. Estou dizendo apenas que a individualidade (ou singularidade), enquanto um conjunto complexo de fatores que condicionam o modo como cada um de nós interpreta o mundo, funciona como o "foco" a partir do qual emanam nossas "verdades", nossos "pensamentos", nossas "falas" e assim por diante. Desse ponto de vista, seria possível estabelecer uma analogia entre o sujeito transcendental kantiano, como um sistema de faculdades determinante do modo como todos nós, enquanto seres racionais, interpretamos o mundo, e esse indivíduo perspectivador nietzschiano como o locus (corpóreo-mental) a partir do qual cada um de nós interpreta o (seu) mundo (cf. Mattos, 2013, pp.86ss). É claro que isso coloca uma série de problemas, entre eles o de um possível solipsismo: se cada um institui e vive em um mundo próprio, como se dá a comunicação entre esses mundos? Ora! Esse problema também se deixaria resolver pelo fato de não se tratar de um indivíduo substancial: ele é uma ficção que permite pensar um foco, mas grande parte dos tais fatores que determinam esse foco vem de "fora" dele, da cultura em que vive, da língua, do clima, da alimentação etc. ${ }^{4} \mathrm{Na}$ medida em que esses fatores são partilhados, é evidente que as perspectivas individuais terão muito em comum umas com as outras, na simples medida em que são instituídas num ambiente comum.

Mas voltemos ao movimento de meu livro. Para assegurar a noção de indivíduo nesses termos, procurei defendê-la em diálogo com posições distintas ao longo do primeiro capítulo. ${ }^{5}$ Assim, busco mostrar que a conhecida crítica de Heidegger a Nietzsche, segundo a qual este seria "o último metafísico do Ocidente" (Heidegger, 2007, p.373), não seria procedente se pudéssemos mostrar o caráter não dogmático de sua filosofia, assentado justamente na consciência de tratar-se apenas da sua

40 próprio Figueiredo aponta para esses fatores em seu texto, ao discutir as limitações do conceito de indivíduo: "O envolvimento do indivíduo pelo inconsciente e pela linguagem, ambos distendidos na história dos costumes e dos povos, sugere que a 'subjetividade humana' passou a abarcar sob si tanto o indivíduo, quanto estruturas determinadas de valoração, que agregam sob um registro indefinido as instâncias pulsional, individual, linguística, religiosa, política e moral, a que talvez possamos dar o nome geral de 'civilização"' (Figueiredo, 2015, p.67).

5 Quanto a isso, devo fazer um parêntese e admitir desde logo que Figueiredo tem certa razão ao dizer que a minha leitura dessas posições já se dá, nesse sentido, sob um "parti pris": consciente ou inconscientemente, eu sabia aonde queria chegar, e procurei mostrar por que tais leituras me pareciam equivocadas. 
filosofia, e não da "verdade" do "mundo". Depois, defendo que a posição predominante entre os intérpretes franceses, que vieram justamente opor-se a Heidegger, pecaria por um relativismo extremo, não dando conta do "lugar de fala" do filósofo Nietzsche. Em seguida, dialogo com a leitura da Profa. Scarlett Marton, que seria próxima às de Müller-Lauter e Günter Abel, e tento mostrar que ver na cosmologia nietzschiana uma alternativa à metafísica tradicional não seria suficiente para refutar a crítica de Heidegger, já que haveria apenas um deslocamento: dogmatismo cosmológico no lugar do dogmatismo metafísico (nos dois casos, porém, havendo a pretensão de dizer a "verdade" do "mundo"). O movimento continua então com a entrada em cena da filosofia analítica, representada por nomes como Peter Poellner e Maudemarie Clark, e a colocação de questões que começariam a preparar o terreno para a minha posição: qual o conceito de verdade de Nietzsche, perguntam-se eles; qual o seu lugar de fala? A minha resposta, como vimos, será a de que o seu lugar de fala é o indivíduo Friedrich Nietzsche, atestando com seu próprio "caso" a validade do perspectivismo como, digamos, uma teoria geral do conhecimento.

Vale frisar que essa não é uma resposta exclusivamente minha: ao assumi-la, aproximei-me de intérpretes como Friedrich Kaulbach, Volker Gerhardt e Antonio Marques, todos eles tendo em comum o estabelecimento de uma continuidade entre o projeto crítico kantiano, lastreado no sujeito transcendental, e o perspectivismo nietzschiano, em que o indivíduo, como vimos, substitui aquele. 0 problema que se coloca para esse tipo de leitura, já antecipado na questão do solipsismo, é o risco de incorrer no relativismo: se tudo o que há são perspectivas diversas, como estabelecer, entre elas, algum tipo de comparação - permitindo dizer, por exemplo, que a perspectiva de Kant ou Nietzsche seria melhor que a de um indivíduo qualquer? De certo modo, é justamente essa a questão que marca a passagem do primeiro ao segundo capítulo de meu livro, quando critérios como vida, saúde e afirmação da vida são mobilizados para explicar, com Nietzsche, a preferibilidade da sua filosofia - a cosmologia da vontade de poder, que seja! - relativamente à filosofia cristã, que, segundo ele, como é sabido, impregna a tradição ocidental como um todo, de Platão a Schopenhauer.

Segundo procuro mostrar, tal preferibilidade se deveria ao fato de ela operar uma radical reaproximação entre homem e mundo: interpretando o indivíduo agora, sim, "substancialmente" - como vir-a-ser, ou como parte ínfima do fluxo de acontecimentos do vir-a-ser, a cosmologia nietzschiana eliminaria a dualidade que alicerça a possibilidade de juízos morais com validade universal e, por extensão, a possibilidade de considerar os indivíduos responsáveis e, portanto, culpáveis por suas ações (donde o problema central da culpa). Vivendo sob o sentimento de culpa (muito bem ilustrado pela noção cristã de pecado original), e acossado por uma autoridade moral imaginária (também ilustrada pelo Deus-pai cristão), o homem 
ocidental teria adoecido progressivamente até chegar ao niilismo que Nietzsche diagnostica em sua época. E somente uma grande transformação no seu modo de ver o mundo - ou, para retomar a chave do perspectivismo, nos valores que presidem o seu criar perspectivo (donde o conhecido mote da "transvaloração de todos os valores") - permitiria reverter esse quadro e "curar" o homem ocidental.

Isso ajudaria, por um lado, a entender o caráter simultaneamente "descritivo" e "normativo" do empreendimento filosófico nietzschiano: ao mesmo tempo em que institui um novo modo de compreender a realidade, fortemente amparado nas descobertas científicas da época, Nietzsche aponta para um outro modo de viver, inspirado em noções como o "além-do-homem", o "espírito livre", a "autossuperação" etc. Por outro lado, contudo, isso nos colocaria frente a um novo problema: como justificar esses elementos "normativos" se a "descrição" da realidade que os acompanha não deixa espaço para noções como "liberdade", "autonomia", "escolha livre" etc.? Teríamos aí, segundo procuro mostrar em meu livro, uma espécie de "antinomia da liberdade", passível de ser formulada em termos semelhantes aos kantianos: (tese) não existe liberdade, pois tudo o que há são vontades de poder cuja "causalidade" não controlamos; (antítese) a liberdade existe nos indivíduos humanos capazes de assumir a responsabilidade pelo próprio destino. E a solução da antinomia, segundo proponho, também poderia ser pensada em termos kantianos (desde que assumidas, naturalmente, as premissas de meu primeiro capítulo): uma vez que essa explicação do mundo - a cosmologia da vontade de poder - é tão somente uma interpretação, não podendo excluir interpretações concorrentes, então seria possível adotar um outro ponto de vista - uma outra perspectiva - para pensar o agir humano, um ponto de vista preferível para estabelecer o caminho ideal a ser percorrido pelo "espírito livre", a saber, o caminho de afirmação radical da própria singularidade, o caminho pelo qual alguém "se torna o que é".

Afastada, assim, a contradição entre a "liberdade" (no sentido que the é atribuído por Nietzsche, ou seja, um sentido centrado na singularidade) e a "vontade de poder" (enquanto princípio de explicação da realidade), eu estaria livre para acompanhar, em chave positiva, o processo de transformação espiritual que conduz à liberdade do indivíduo enquanto um novo modo de vivenciar a realidade. É este, com efeito, o objetivo do terceiro capítulo, em que me afasto um pouco da discussão com os comentadores e passo, digamos, a dar vida aos personagens nietzschianos em sua cruzada anticristã. Daí o título desse capítulo ser "singularidade versus universalidade: a guerra do espírito livre", e seus subtítulos se constituírem como momentos dessa "guerra": reconhecimento do inimigo, preparação para o combate, espionagem do inimigo, lançamento da ofensiva, avanço sobre as linhas inimigas. Não me deterei mais nesse capítulo, por ora, tendo em vista que a artilharia crítica de Figueiredo, para aproveitar o contexto bélico das metáforas, deixa esse território 
praticamente intocado (muito embora ele forneça pistas importantes para contornar algumas críticas).

Já o quarto e último capítulo, o menor de todos e, em certo sentido, o menos integrado ao núcleo da tese (mas ao mesmo tempo o mais polêmico!), recebe um pesado bombardeio do nosso autor. Tendo estabelecido uma espécie de "ética da autenticidade" (para usar uma fórmula que é cara a Charles Taylor (2011)) no capítulo anterior, eu me coloco nesse momento final da tese o desafio de pensar a política a partir dessa ética: se é possível, como eu proponho, pensar a partir de Nietzsche um caminho de autorrealização singular por meio do indivíduo que conquista a liberdade em sentido perspectivista, que modelo de sociedade seria o melhor para esse mesmo indivíduo, ou para o potencial florescimento de indivíduos como ele? Minha resposta é a de que um mínimo de garantias democráticas seria preferível a um sistema autoritário e arbitrário que pudesse, por exemplo, cercear a liberdade de expressão. Ou seja: eu tive a ousadia (ou talvez a temeridade!) de propor a "ideia insólita", nas palavras de Figueiredo, ${ }^{6}$ de combinar Nietzsche e democracia.

De fato: eu proponho essa associação, mas ela se dá, como visto, numa espécie de "apêndice" ou "excurso" à tese principal, procurando pensar a política a partir de uma ética centrada na singularidade que (esta, sim!) eu teria conseguido demonstrar em meu percurso - a partir de Nietzsche, mas convencido de estar próximo ao espírito de sua filosofia (o que já não posso afirmar, é verdade, sobre a defesa da democracia). Como, em todo caso, boa parte da "visibilidade" que o livro adquiriu, por assim dizer, diz respeito a essa polêmica aproximação, não posso furtar-me a tentar defendê-la das críticas, entre as quais as de Figueiredo. Antes, porém, de discutir essa questão específica, vejamos como Figueiredo constrói sua crítica, começando por apontar aqueles que seriam os dois objetivos da tese:

De um lado, [o autor] quer mostrar que há um nexo forte entre Kant e Nietzsche, e que tomá-lo em conta fornece a melhor solução das inúmeras dificuldades e aporias que atravessam o debate sobre as interpretações do texto nietzscheano. De outro, e na parte final do livro, Mattos confere à interpretação de seu autor um desdobramento político, ao sustentar que a democracia constitui a forma de governo que melhor assegura o antidogmatismo e a "liberdade individual em sentido perspectivista" - as duas posições filosóficas fundamentais que Nietzsche teria atingido, ao seguir a trilha aberta por Kant (Figueiredo, 2015, p.51).

Com relação a isso, eu faria desde logo uma primeira ressalva: embora Figueiredo pareça ver como momentos distintos e complementares o estabelecimento do vínculo entre Kant e Nietzsche e a sua utilização para solucionar problemas internos ao pensamento nietzschiano, é preciso insistir na maior importância deste último, pois a aproximação com Kant não é efetuada como um fim em si mesmo;

6 "Um Nietzsche democrático é uma ideia insólita" (Figueiredo, 2015,p.52). 
trata-se antes de uma estratégia para enfrentar questões surgidas na minha tal "reflexão a partir de Nietzsche", tendo em vista o objetivo maior de, como aqui mostrado, defender a liberdade no contexto de uma ética da autenticidade (objetivo que Figueiredo não menciona no início, mas que levará em conta mais adiante). Quanto ao segundo objetivo mencionado por Figueiredo (a defesa da democracia "como forma de governo que melhor assegura o antidogmatismo"), voltaremos a ele adiante.

Num primeiro momento, o artigo de Figueiredo se concentra na discussão desse que seria o primeiro de meus objetivos: estabelecer o vínculo entre Kant e Nietzsche. Para tal, ele reconstrói o movimento de meu primeiro capítulo - o que também fiz aqui há pouco - e procura mostrar que, embora eu dê ao texto a aparência de uma discussão aberta com os comentadores, o resultado da discussão já estaria dado de antemão, em vista do meu parti pris contra os franceses e, em certo sentido, a favor dos intérpretes analíticos de Nietzsche - que colocariam a exigência de prestar contas dos pressupostos de sua fala "de fora", a partir de um registro teórico diverso do nietzschiano. Como dito anteriormente, penso que Figueiredo tem uma certa razão quanto a isso: em minhas leituras da época, acredito que os filósofos analíticos acabaram por influenciar significativamente a minha própria análise da questão do conhecimento em Nietzsche, reforçando a adoção de um ponto de vista externo à obra, calcado numa concepção específica de verdade, e ajudando a pavimentar meu caminho na direção da aproximação com Kant. ${ }^{7}$

Isso também explicaria, segundo Figueiredo, outra posição que ele critica: a equiparação de metafísica e dogmatismo, como se todo discurso dogmático fosse necessariamente metafísico. Nas palavras do nosso autor, analisando uma passagemchave de minha argumentação no primeiro capítulo,

conclui-se daí que, se pudermos inverter a abordagem de Heidegger, tomando o perspectivismo como "teoria do conhecimento", estaremos isentando Nietzsche de ser dogmático ou metafísico. Nisto há uma questão prévia, sobre a qual Mattos não se detém: será que "dogmático" e "metafísico" são necessariamente sinônimos, como se supõe aqui? (Figueiredo, 2015, p.55).

A questão é pertinente e demanda um esclarecimento. De fato, tais termos não são sinônimos, mas, segundo textos do próprio Nietzsche que analiso em meu livro, seria possível dizer que todo dogmatismo tende a ser metafísico na medida em que

\footnotetext{
7 Nas palavras de Figueiredo: "Podemos nos perguntar se isso é um bom motivo para decidir-se por esta ou aquela interpretação. Afinal, os mencionados quesitos requeridos pelo pensamento crítico também possuem uma origem, merecendo, assim, atenção genealógica e senso histórico. Tomálos como parâmetros situados acima dos filósofos implica aceitar de partida a invariabilidade e necessidade de certos critérios que se aplicariam indiferentemente a cada uma das filosofias. Tal premissa atesta a presença de um conceito determinado do que deva ser a filosofia ou dos critérios a que devem se submeter os enunciados filosóficos, ambos alheios a Nietzsche" (Figueiredo, 2015, p.54).
} 
assume, para julgá-lo, algum padrão externo à realidade deste mundo (que é vir-aser e, portanto, não comporta verdades imutáveis). Daí, por exemplo, que o primeiro ato da "História de um erro", no Crepúsculo dos ídolos, seja Platão afirmando "eu, Platão, sou a verdade" (Nietzsche, 2006, p.137): trata-se de transformar o próprio juízo em verdade universal, algo que Nietzsche critica duramente em diversas outras passagens (inclusive quando em diálogo com Kant). Se o dogmatismo consiste em acreditar possuir a verdade, isto significa que, para Nietzsche, todo dogmatismo inclusive o científico, como ele mostra em Gaia Ciência $(373)^{8}$ - supõe alguma crença metafísica, quer explícita ou implícita. Assim, eu realmente concluiria pelo caráter metafísico e dogmático do pensamento nietzschiano se ele houvesse acreditado encontrar "a verdade" do mundo.

Se é evidente, porém, que todo dogmático é metafísico, o inverso não é verdadeiro (e este é um ponto fundamental na minha tese que Figueiredo parece não ter notado): nem todo metafísico é necessariamente dogmático. Se, conforme a minha tese, o que caracteriza o antidogmatismo é a aceitação do caráter perspectivo do próprio discurso, então nada impede que um indivíduo proponha hipóteses metafísicas sem afirmá-las dogmaticamente. Teria sido este o caso do próprio Nietzsche, ao apresentar a vontade de poder como "interpretação, e não texto", no § 22 de Além de bem e mal, ou como suposição, no § 36 da mesma obra (Nietzsche, 2005, Livro I). E isto não seria um problema, desde que admitido o caráter hipotético, interpretativo e pessoal dessa ideia, do mesmo modo como já não era um problema o sujeito transcendental kantiano elaborar as suas (nossas) hipóteses sobre o supra-sensível tendo por base os dados (subjetivos) da razão prática. Nos dois casos, e principalmente no de Nietzsche, teríamos aquilo que Volker Gerhardt chamou de "metafísica crítica" (cf. Gerhardt, 1989). Assim, o verdadeiro ponto, na disputa com a interpretação "cosmológica" de Nietzsche, não é tanto sobre ele ser ou não metafísico, mas sobre ser ou não dogmático: em não o sendo, pouco importa se chamamos "metafísica" ou "cosmologia" à perspectiva da vontade de poder.

Mas a questão que realmente importa, a meu ver, nessa crítica de Figueiredo, diz respeito à convicção de fundo, aí expressa, de que o único modo de salvar Nietzsche do dogmatismo seria a interpretação do perspectivismo como uma teoria do conhecimento centrada no indivíduo. Que seja dada a palavra ao nosso autor, com a ressalva de que, segundo o que acabamos de dizer, a palavra "metafísica" seja substituída aí por "dogmatismo":

Se o fenômeno do niilismo ensina que o simples fato de sermos críticos não nos impede de permanecermos metafísicos, então Nietzsche devia estar ciente de que a verdadeira superação da metafísica não depende de encontrarmos uma justificativa metodológica para nossa fala e nossos enunciados, até porque o método pode servir a senhores diferentes. Sob esse aspecto, a superação da metafísica requer outro

8 "'Ciência' como preconceito" - Nietzsche, 2001, pp.276 e ss. 
pensar, isento da referência ao incondicionado - e é nesta direção que a ideia de uma "cosmologia não metafísica" adquire seu interesse. (...) Suponha, porém, que as "forças cósmicas" permanecem sendo tudo o que há, sem remissão a qualquer exterioridade; nesse caso, o caráter não metafísico reivindicado para essa cosmologia será inequívoco (Figueiredo, 2015, p.58).

Que se trata de encontrar uma cosmologia não metafísica, ou, como eu preferiria colocar, uma metafísica ou cosmologia (Schopenhauer já nos mostrara que uma metafísica pode ser imanente ao mundo!) não dogmática, estamos então de acordo. A questão é saber se o que nos leva até ela é encontrar "uma justificativa metodológica para nossa fala e nossos enunciados", ou se, supondo essa exigência (como quer Figueiredo) ancorada em pressupostos externos (kantianos e analíticos) não só à letra do texto nietzschiano, mas também ao seu espírito, é preciso encontrar "outro pensar, isento da referência ao incondicionado" (que ainda estaria implícita na pretensão do nosso indivíduo a instituir a perspectiva do seu mundo como se este fosse absoluto). E aqui Figueiredo me parece ir de fato ao "X da questão", àquilo que de fato opunha, como um Leitmotiv oculto, a minha interpretação à de Scarlett, Müller-Lauter e Abel: eu temia que, aceitando a virada para um pensar radicalmente outro, que aceita as "forças cósmicas" como "tudo o que há" e desfaz as fronteiras entre o eu e o mundo, Nietzsche se tornaria um Heidegger avant la lettre, apontando para um misticismo "irracional" que inviabilizaria a própria ideia de uma ética da autenticidade. Resumindo numa fórmula irônica, eu poderia dizer que li Nietzsche agarrado em Kant para não ser engolido por Heidegger!

Claro: alguém poderia desde logo questionar o porquê desse binarismo Kant ou Heidegger. Adianto que, a meu ver, a resposta a essa questão passa pela análise heideggeriana da questão da verdade, que ecoa em certa medida a análise nietzschiana e estabelece uma clivagem entre a verdade como correspondência (também duramente criticada por Nietzsche) e a verdade como alétheia, no sentido dos pré-socráticos (também valorizados por Nietzsche). Antes de passar a ela, porém, vejamos como o próprio Figueiredo nos incita a procurar uma terceira via em relação a esse dilema. Se, em certo sentido, o meu paralelo de Nietzsche com Kant se baseia mais na primeira do que nas demais Críticas deste último filósofo, Figueiredo sugere que esse paralelo talvez fosse mais produtivo recorrendo em vez disso à terceira, a da faculdade de julgar, e ao domínio do juízo reflexionante. É o que faz o já citado Antonio Marques, e o que também nós poderíamos fazer, segundo Figueiredo, se abandonássemos o vínculo entre o pensar "fora" da física e a meta-física dogmática (vínculo que eu teria por pressuposto, como vimos):

Estaríamos livres para cogitar outro cenário, em que o elemento crítico ressaltado pelo kantismo fosse apresentado isento de seu motivo metafísico? Isso equivaleria a descobrir uma via que nos desviasse do caminho bem pavimentado que conduz do incondicionado como "simples ideia" da razão pura ao Saber Absoluto hegeliano. 
Contornando a referência do lógos ao incondicionado, poderíamos dispensar as ideias da "Dialética transcendental da razão pura" como parâmetros regulativos do conhecimento - e arriscar oferecer uma base puramente "reflexionante" para a atitude crítica, que se veria, dessa forma, enraizada de uma vez por todas na produtividade da imaginação transcendental (Figueiredo, 2015, p.59).

Sim, esse é um caminho interessante, e nos permitiria "fundar" o discurso filosófico não mais no incondicionado de uma razão universal, mas na "universal" produtividade de uma imaginação cujas regras, ocultas em seu peculiar jogo, seriam de algum modo incorporadas pelo gênio. O "espírito livre" nietzschiano poderia ser pensado em paralelo com o "livre jogo das faculdades" que se manifesta no "gênio" kantiano (um paralelo para o qual me chamou atenção, recentemente, o amigo João Constâncio, da Universidade Nova de Lisboa): de caráter regulativo, não mais constitutivo, o discurso a ser assim gestado seria perspectivo, porque instaurado a cada caso pelo gênio espiritual do filósofo-artista (figura sabidamente valorizada por Nietzsche), mas não seria inteiramente relativo. Atingiríamos o mesmo propósito que eu buscava - a liberdade de criação como parâmetro para uma vida ética autêntica sem pagar o preço de uma teoria do conhecimento fundada no indivíduo (noção cujos problemas salientei desde o princípio).

Não à toa, é no Romantismo de Novalis que Figueiredo irá encontrar os ecos desse Kant reflexionante e, ao mesmo tempo, os prenúncios de um Nietzsche que teria na "estilística da existência" (para usar uma expressão de Giacoia (2012), citado por Figueiredo) o núcleo de sua filosofia. Segundo Figueiredo,

antes de findar o século XVIII, Novalis chamava a atenção para o caráter individual do filosofar, para as filosofias individuais: "O método é genuinamente filosófico Elas partem do absoluto - só que não de um absoluto puro." O absoluto, ou seja, o incondicionado que víramos sair ileso, mas "subjetivado" do tribunal crítico kantiano e, assim, incorporado às faculdades que tornam o conhecimento necessário e universal, vê-se repentinamente contaminado pelo que há de individual no filosofar. Abstraídas todas as mediações interpostas no trajeto que vai de Novalis a Nietzsche, não se adivinha na impureza desse incondicionado - saudado por Novalis como genuíno, a despeito disso - algo do perspectivismo buscado por Mattos, o perspectivismo visto como aprofundamento modificador do "sujeito crítico" kantiano? (Figueiredo, 2015, p.62).

"Sim!", anotei eu à margem do texto, quando o lia pela primeira vez: o mundo que o "espírito livre" nietzschiano vislumbra, quando rompe com o dogmatismo e estabelece a sua interpretação da realidade, faz lembrar o incondicionado impuro de Novalis - "o mundo voltou a ser infinito para nós", como diz Nietzsche em Gaia ciência, 343 (Nietzsche, 2001, p.234). O verdadeiro problema está, talvez, no excesso de importância que dei ao caráter interpretativo do filosofar, ignorando a famosa ironia com que Nietzsche encerra o parágrafo 22 de Além de bem e mal: "Posto que também isto seja somente interpretação - e sereis bastante zelosos para fazer essa objeção? - ora, tanto melhor!" (Nietzsche, 1983, p.272). O que importa é que a realidade está 
aí, diante de nós, e já não estamos sob o jugo de uma "verdade" - um dogma, um incondicionado absoluto - para interpretá-la (e estamos sempre interpretando, quer queiramos ou não). A ruptura com o dogmatismo abre o indivíduo para o mundo, torna necessariamente mais leve a sua relação com o mundo - e tanto faz, no limite, como interpretá-lo; o que importa agora é como vivê-lo. E aí passaríamos ao terceiro capítulo de meu livro, que, como dito, mereceu pouca atenção dos leitores (ou, no caso de Figueiredo, se deixou reduzir - não sem boas razões - à saudável aproximação com Novalis). Pois lá enxergamos em chave positiva essa abertura para o mundo, assim descrita pelo filósofo na mencionada passagem de A gaia ciência (343):

De fato, nós filósofos e "espíritos livres" sentimo-nos, à notícia de que "o velho Deus está morto", como que iluminados pelos raios de uma nova aurora; nosso coração transborda de gratidão, assombro, pressentimento, expectativa - eis que enfim o horizonte nos aparece livre outra vez, posto mesmo que não esteja claro, enfim podemos lançar outra vez ao largo nossos navios, navegar a todo perigo, toda ousadia do conhecedor é outra vez permitida, o mar, nosso mar, está outra vez aberto, talvez nunca dantes houve tanto "mar aberto" (Nietzsche, 2001, p.234).

De certo modo, esse movimento de abertura corresponde à transição para o "outro pensar, isento da referência ao incondicionado" que vimos Figueiredo cobrar-nos há pouco. 0 que me faltou perceber em meu livro foi, talvez, o fato de que a interpretação importa pouco nesse movimento, porque é o próprio movimento, a própria abertura, o que está em causa: o como do viver-interpretar, e não o seu "conteúdo", os seus "conceitos", aquilo que ele "representaria" (mesmo hipoteticamente) da realidade. Está em jogo o que acontece na obra do filósofo, o que brota dessa abertura ao mundo na forma de palavras, cujo conteúdo importa menos que a forma, o estilo, a musicalidade (elementos enfatizados por Derrida (1978)). É como se o discurso filosófico devesse servir agora ao próprio mundo, dando-lhe a palavra - não é outra coisa, com efeito, o que diz Zaratustra à solidão na seção Die Heimkehr ("O regresso" ou "A volta ao lar"):

Ó solidão! Ó solidão, minha pátria! Tempo demais selvagemente vivi em selvagens terras estranhas, para não voltar a ti sem lágrimas. / (...) Ó solidão! Ó solidão, minha pátria! Quão feliz e meiga me fala a tua voz! / Não nos interrogamos um ao outro, não nos queixamos um ao outro, juntos transpomos, abertamente, portas abertas. I Porque em ti é tudo aberto e claro; e também as horas correm, aqui, com pés mais leves. No escuro, de fato, torna-se o tempo mais pesado do que na luz. / Abrem-se para mim, aqui, todas as palavras e cofres de palavras do ser: todo ser quer aqui tornar-se palavra, todo devir quer aqui aprender comigo a falar (Nietzsche, 1998, pp.189-90).

Como veem, a paisagem já não é nem um pouco königsbergiana, para jogar com uma metáfora de Figueiredo; ela está bem mais, agora, para uma paisagem de floresta do sudoeste alemão. Pois é Heidegger quem conceberá a superação da metafísica exatamente nesses termos: abertura para o ser, que antes se encontrava 
encoberto (encoberto, justamente, pelo modo dogmático com o qual os filósofos da tradição ocidental quiseram definir o ser em termos conceituais). Se, ao contrário do que quer Heidegger em sua leitura de Nietzsche, a vontade de poder for menos um conceito do que uma chave de abertura para a pluralidade das forças que se sucedem no tempo, então Nietzsche estaria a um passo de Ser e Tempo. Mas Heidegger talvez não quisesse admitir essa proximidade, e tenha preferido ler na noção nietzschiana um conceito em sentido forte, ainda inscrito na concepção da verdade como correspondência ao mundo, e não da verdade como alétheia, como revelação ou desencobrimento (pensando na conhecida distinção que Heidegger estabelece no § 44 dessa obra (Heidegger, 2005, pp.287ss)). Ora! Mas o que vemos acontecer com Zaratustra não é exatamente o "acontecimento" da "verdade" neste segundo sentido? Nietzsche também não parece muitas vezes indicar a "revelação" como um modo de desencobrimento do ser? Veja-se, por exemplo, a seguinte passagem do Ecce homo, falando justamente sobre o Zaratustra:

A noção de revelação, no sentido de que subitamente, com inefável certeza e sutileza, algo se torna visível, audível, algo que comove e transtorna no mais fundo, descreve simplesmente o estado de fato. Ouve-se, não se procura; toma-se, não se pergunta quem dá; um pensamento reluz como relâmpago, com necessidade, sem hesitação na forma (Nietzsche, 2003, pp.85-86). ${ }^{9}$

É claro que haveria muitas diferenças a sublinhar entre os dois filósofos, mas trechos como esse permitiriam explorar diversas semelhanças (entre esse "estado de fato" e a "facticidade" heideggeriana; entre essa "descrição" e a descrição fenomenológica; a questão da escuta; etc.). E nos levariam a perceber uma proximidade bem maior entre Nietzsche e Heidegger do que entre Nietzsche e Kant, sugerindo ver naquele um momento na linha que conduz do misticismo romântico de Novalis a Heidegger, passando por Schopenhauer - um diagnóstico que, ao que tudo indica, Figueiredo endossaria. E essa leitura não me impediria necessariamente de perseguir a ética da autenticidade, visada em meu terceiro capítulo: ainda que o indivíduo volte a tornar-se fortemente problemático nessa chave, minha hipótese de trabalho continua válida - para Nietzsche e talvez para o próprio Heidegger - se lembrarmos que o "indivíduo" por mim advogado não é um indivíduo substancializado ou "ontológico". Ele diz respeito ao ponto de vista ôntico, para insistir agora na terminologia heideggeriana: trata-se do indivíduo de carne e osso que, sob o domínio do impessoal, não pode, a princípio, reconhecer-se de outro modo (ainda mais na modernidade ocidental!) senão como "eu". E este "eu" terá de libertar-se, de abrir-se ao ser, para poder reconhecer-se, aí sim, como "ser-no-mundo". Do ponto de vista

9 Como aponto em meu livro, "na sequência do texto, interessante notar, Nietzsche se refere à seção "O regresso", já por nós citada, onde se tem de fato uma bela descrição desse mesmo estado de ânimo, similar ao de uma revelação divina, por meio da qual Zaratustra como que recebe do mundo os símbolos de que se vale para dele falar" (Mattos, 2013, p.142). 
dele, o caminho para a autenticidade pode ser pensado como um caminho ético de abertura e realização de suas possibilidades mais próprias ou singulares.

Em que pese a rapidez do salto que demos, ele nos permite retornar à questão da democracia, numa consideração ainda mais insólita do que a primeira: além de um Nietzsche democrático, vamos falar agora de um Heidegger democrático? Se já era difícil imaginar o "espírito livre" indo votar em dia de eleição, como ironiza Figueiredo, que dizer então do Dasein caipira, cujos vínculos com o nazismo são cada vez mais claros? De fato: é realmente difícil pensar a democracia - e estamos vendo hoje, no Brasil, como é perigoso não pensar a democracia - a partir de uma ética da autenticidade, um problema que se coloca não somente a partir desses dois autores, mas, como nos mostra Figueiredo, de Novalis e de todos que vão nessa direção:

Quando, por exemplo, "liberdade individual" e "universalidade formal” dão-se as costas, a "autonomia" perde a ligação interna que a unia com a legislação jurídica. Convertendo-se em ideal de autenticidade ou núcleo subjetivo avesso à vontade geral, a autonomia torna cada vez mais remota a transição que antes lhe fora confiada, a passagem da moral ao direito; e não demorará para encontrarmos este último sendo visto pelo indivíduo como pura exterioridade, irredutível à sua autodeterminação (M. Stirner, S. Kierkegaard, K. Marx). Não surpreende encontrarmos Nietzsche advertindo-nos sobre os riscos da dissolução do indivíduo no regime de universalidades consagradas pelos tempos modernos. Neles, desaparece tudo o que há de próprio e desigual nos homens - como apregoam os "direitos iguais" e o "espírito democrático" (Figueiredo, 2015, p.63).

Essa é, de fato, uma dificuldade e tanto. Como eu disse no princípio, minha entrada no tema da democracia, ao final da tese, foi menos um movimento necessário do texto que um apêndice no qual me perguntei sobre os possíveis desdobramentos políticos da ética a que eu havia chegado. Foi como se eu parasse e me perguntasse: "Pois bem! E agora? E a política?" Uma resposta possível seria dizer que Nietzsche deu as costas à política; e que Heidegger, depois do fracasso na experiência do reitorado, teria feito o mesmo; que, enfim, seria possível pensar uma ética como estilística da existência e deixar a questão política de lado. Mas deixar a política de lado - volto a lembrar o atual momento brasileiro - não parece algo muito razoável, para alguém que se dedica à filosofia. Por outro lado, também não parece razoável deixar de lado filosofias que foram tão fundo na reflexão sobre a alma humana pelo fato de não terem tematizado adequadamente a política. Eis o que eu considero um grande dilema da filosofia contemporânea.

Em artigo que escrevi para a seção "Estante", da ANPOF, sobre o já citado livro Nietzsche x Kant, do também amigo Oswaldo Giacoia Jr, coloquei-me essa mesma questão, suscitada pelo impasse que o próprio Giacoia havia caracterizado, ao mostrar certos pontos de incompatibilidade entre os dois filósofos. Na ocasião, sugeri utilizar a distinção feita por Habermas entre os usos pragmático, ético e moral da razão prática como uma possível saída: Nietzsche forneceria uma chave mais 
interessante para pensar o uso ético (da autorrealização individual); Kant forneceria um quadro teórico preferível para pensar o uso moral (das normas de caráter universal); e um serviria de contrapeso ao outro, Nietzsche sendo mais interessante para fazer a crítica da sociedade, Kant estabelecendo limites à "guerra (pessoal) do espírito livre". Evidentemente, trata-se de uma saída um tanto artificial, mas que, em alguma medida, permitiria sair desse tão contemporâneo dilema (singularidade versus universalidade) - que se manifesta, por exemplo, na disputa entre liberais e comunitaristas.

Mas eu me pergunto hoje, no contexto dessa aproximação entre Nietzsche e Heidegger, e pensando numa direção semelhante à de Charles Taylor, se a abertura ao ser, entendida como algo mais do que uma mera hipótese (que é como ela aparecia em minha tese), não poderia constituir um caminho interessante para pensar, na linha do cuidado heideggeriano, uma outra atitude (coerente com esse "outro pensar") não apenas em relação a si próprio (o Dasein individual), mas ao mundo e ao outro (o Mitdasein); e, a partir dela, também uma outra configuração social e política. Será sempre necessário, a meu ver, pensar a política a partir desses quadros teóricos (e não internamente a eles), e dialogar com autores que partem dos mesmos quadros (nesse caso, autores como Hannah Arendt, Herbert Marcuse e Hans Jonas). Em termos muito gerais, trata-se de encontrar uma face política positiva minimamente democrática nesse grande arco de filosofias que, na esteira da terceira Crítica kantiana e do Romantismo alemão, buscam algum modo de acessar o ser sem incorrer no dogmatismo.

Seja como for, independentemente de encontrarmos essa face política, fato é que a nossa pergunta do título poderia muito bem ser, a essa altura, relida às avessas: seria Heidegger um nietzschiano? Se está certa a crítica de Figueiredo a meu livro, talvez sim: a metafísica dualista do Ocidente já estava superada em 1885, com o Zaratustra de Nietzsche. E Figueiredo nos leva a ampliar o arco da questão e perguntar: será que essa história não começa quase cem anos antes, em 1790, com a Crítica da faculdade de julgar? Eis a questão com que eu gostaria de encerrar esta breve reflexão, agradecendo novamente ao Vinicius Figueiredo pelas preciosas sugestões filosóficas.

\section{Referências}

Derrida, J. (1978). Eperons. Les styles de Nietzsche. Paris: Flammarion.

Figueiredo, V. (2015). Seria Nietzsche um kantiano? Cadernos de Filosofia Alemã: Crítica e Modernidade, 20(1), pp.51-72.

Gerhardt, V. (1989). Die Perspektive des Perspektivismus. Nietzsche-Studien, 18, pp.260-281.

Giacoia Jr., O. (2012). Nietzsche X Kant: uma disputa permanente a respeito de 
liberdade, autonomia e dever. Rio de Janeiro: Casa da palavra.

Gori, P. e Stellino, P. (2014). O perspectivismo moral nietzschiano. Cadernos Nietzsche, 34(I), pp.101-129.

Heidegger, M. (2007). Nietzsche, vol. I. Tradução de Marco Antonio Casanova. Rio de Janeiro: Forense.

. (2005). Ser e tempo, vol. I. Tradução de Márcia Cavalcanti Schuback. Petrópolis: Vozes.

Mattos, F. C. (2013). Nietzsche, perspectivismo e democracia: um espírito livre em guerra contra o dogmatismo. São Paulo: Saraiva.

Müller-Lauter, W. (2009). Nietzsche - sua filosofia dos antagonismos e os antagonismos de sua filosofia. Tradução de Clademir Araldi. São Paulo: Ed. Unifesp.

Nietzsche, F. (2001). A gaia ciência. Tradução de Paulo César de Souza. São Paulo: Cia. das Letras.

- (2005). Além do bem e do mal. Tradução de Paulo César de Souza. São Paulo: Cia. das Letras (Cia. de Bolso).

- (1998). Assim falou Zaratustra. Tradução de Mário da Silva. Rio de Janeiro: Bertrand Brasil.

- (2006). Crepúsculo dos ídolos. Tradução de Paulo César de Souza. São Paulo: Cia. das Letras.

Cia. das Letras.

- (2003). Ecce Homo. Tradução de Paulo César de Souza. São Paulo:

- (1983). Obras incompletas. Tradução de Rubens Rodrigues Torres Filho. São Paulo: Abril Cultural (coleção "Os Pensadores").

Taylor, C. (2011). A ética da autenticidade. Tradução de Talyta Carvalho. São Paulo: É Realizações. 